\title{
The Maoist Revival and the Conservative Turn in Chinese Politics
}

Willy Lam

\section{(2) OpenEdition}

1 Journals

Electronic version

URL: http://journals.openedition.org/chinaperspectives/5851

DOI: 10.4000/chinaperspectives.5851

ISSN: 1996-4617

Publisher

Centre d'étude français sur la Chine contemporaine

\section{Printed version}

Date of publication: 4 June 2012

Number of pages: 5-15

ISSN: 2070-3449

\section{Electronic reference}

Willy Lam, «The Maoist Revival and the Conservative Turn in Chinese Politics », China Perspectives

[Online], 2012/2 | 2012, Online since 30 June 2012, connection on 28 October 2019. URL : http:// journals.openedition.org/chinaperspectives/5851; DOI : 10.4000/chinaperspectives.5851 


\title{
The Maoist Revival and the
}

\section{Conservative Turn in Chinese Politics}

\author{
WILLY LAM
}

\begin{abstract}
This paper evaluates the revival of Maoism in China as major factions of the Chinese Communist Party take a conservative turn in ideology and politics. While the changhong ("singing red songs") campaign spearheaded by the ousted party chief of Chongqing, Bo Xilai, has attracted the most attention in and outside of China, power blocs ranging from the Communist Youth League Faction under President Hu Jintao to the Gang of Princelings headed by Vice-President Xi Jinping have also resuscitated different aspects of the teachings and values associated with the Great Helmsman. For this reason, the political demise of Bo does not mean the cessation of the revive-Maoism phenomenon. This study also assesses the impact of the restoration of Maoist norms on aspects of Chinese politics such as the future of political reform.
\end{abstract}

KEYWORDS: Maoism, conservatism, dissent, princelings, political reform.

\section{Introduction and synopsis}

A ccording to former Soviet leader Mikhail Gorbachev's mid-2011 interview with the BBC, Nikita Khrushchev's 1956 denunciation of Stalin had a pivotal impact on his new thinking, including the germination of the ideas of perestroika and glasnost. (1) Yet in China, nobody - and no political force - has the guts, integrity, and vision to publicly unmask and denounce Chairman Mao Zedong, who many believe to have been responsible for more deaths than Stalin.

Since the Cultural Revolution, the closest that the Chinese Communist Party (CCP) authorities have come to evaluating the mistakes of Mao Zedong is the famous Resolution on Certain Historical Questions of the CCP since the Establishment of the People's Republic (hereafter Resolution), which was passed by the CCP Central Committee in 1981 under the close supervision of Deng Xiaoping. The Resolution pointed out unequivocally that Mao's "contributions to the Chinese revolution far outweighed his shortcomings" and that "his contributions were primary, his mistakes secondary." (2) Moreover, the document's criticisms of Mao centred on tactical issues, mainly errors of judgment during the Cultural Revolution. Not one word was devoted to the irrational and non-democratic nature of Maoism or to Mao's feudalistic governance. As Deng said at the time: "We must affirm the historical position of comrade Mao Zedong, and uphold and develop Mao Thought. We must hoist high the flag of Mao Thought not only today but in the future." (3) Fourth-Generation leader President Hu Jintao was equally effusive in eulogising the demigod. In a speech marking the Great Helmsman's 110th birthday in late 2003, he declared Mao to be a "great proletarian revolutionary strategist and theorist." While Deng at least cited "leftist" errors committed by Mao, Hu's hagiographic address made no mention of his manifold blunders. ${ }^{(4)}$

This paper studies the background and significance of the Maoist revival that began in Chongqing in late 2008 - and which spread across the nation in the ensuing years. On 15 March 2012, Bo Xilai, the main progenitor of the crypto-Maoist revival, was relieved of his position as Chongqing Party secretary. Soon afterwards, his membership in the Politburo and Central
Committee was suspended. There is no indication, however, that the resuscitation of Maoist norms has been halted due to Bo's downfall. What, then, are the factors behind the quasi-Maoist renaissance, which has manifested itself in phenomena and campaigns ranging from changhong (singing red songs) to the apparently new fad of constructing a "red GDP"? The relationship between the rekindling of Maoist norms and the Hu Jintao leadership's top agenda of upholding political stability is examined. Also discussed are the factional dynamics behind the re-hoisting of Maoist banners. For example, are the princelings - who seemed to be at the forefront of the political movement - singing Mao's praises so as to consolidate the political fortune of the so-called Gang of Princelings? The policy implications of changhong and other Maoist rituals are also studied. This paper will also look at the significance of the restitution of Maoism particularly with reference to the party's potentials for reform after the pivotal $18^{\text {th }}$ CCP Congress of late 2012 .

\section{The genesis and major contours of the Maoist restoration}

\section{Revival of Maoist statues, "red songs," and Maoist quotations}

The revival of Maoism started in 2008 and culminated in festivities surrounding the $90^{\text {th }}$ birthday of the CCP on 1 July 2011. The epicentre of the revitalisation of Maoist norms is the western metropolis of Chongqing,

1. Cited in "Gorbachev - The Great Dissident," BBC World Service, August 2011, www.bbc.co.uk/ news/world-europe-14507036 (consulted on 3 March 2012).

2. "Resolution on certain historical questions of the party since nation-building," Xinhua News Agency, 27 June 1981, http://news.xinhuanet.com/ziliao/2002-03/04/content_2543544.htm (consulted on 3 March 2012).

3. Cited in Deng Xiaoping, "Opinions on drafting 'Resolution on certain historical questions of the party since nation-building'," Xinhua News Agency, 22 June 1981, http://news.xinhuanet.com/ziliao/2005-02/04/content_2548121.htm (consulted on 3 March 2012).

4. "Hu Jintao's speech at the forum commemorating the 110th birthday of Mao Zedong," People's Daily, 6 December 2003, http://cpc.people.com.cn/GB/69112/70190/70193/14286125.html (consulted on 3 March 2012). 


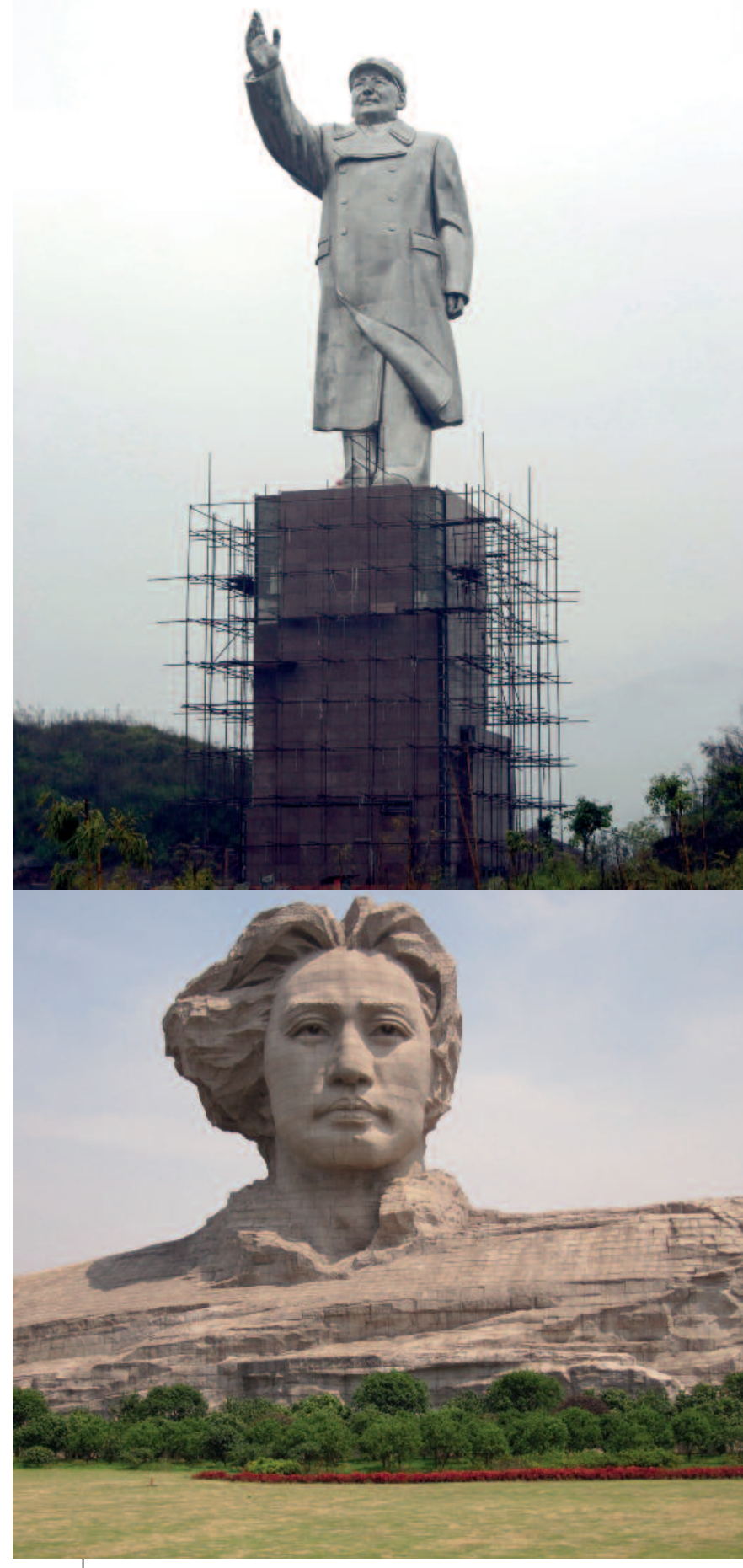

Top: The 20.6-meter-tall stainless steel statue of Mao Zedong at Chongqing Medical University in Chongqing.

Credits: Zhong Guilin, Imagechina.

Bottom: Mao Zedong youth art sculpture, Changsha. Credits: Huang Dan/Wikimedia.

which became the base of then-Party secretary Bo Xilai when the ambitious and charismatic son of Party elder Bo Yibo (1908-2007) was transferred there in late 2007. Mao statues - which were feverishly torn down all over China soon after late patriarch Deng Xiaoping initiated the reform era in 1978 - were put up again by government offices, factories, and universities in this city of 34 million people. A newly constructed seven-story statue of the demigod in Chongqing's college district dwarfed nearby halls, libraries, and classroom buildings. ${ }^{(5)}$ The Maoist fever soon spread elsewhere. Not far from the Helmsman's birthplace in the middle of Xiangjiang River in Changsha, Hunan Province, the latest tourist attraction was a sky-scraping, 32-meter torso of the young Mao. Moreover, the long-forgotten slogan "Long Live Mao Zedong Thought" was resuscitated in October 2009 after banners bearing this battle cry were held high by college students and nationalistic Beijing residents during parades in Tiananmen Square that marked the 60th birthday of the People's Republic. (6)

Yet the most vivid - and telling - symbol of the restitution of Maoist standards is the changhong (literally, "singing red songs") campaign, which had become a near-universal phenomenon in the run-up to the 1 July 2011 celebration of the Party's $90^{\text {th }}$ birthday. Song-and-dance troupes that specialised in red songs, whose participants ranged from high-school students to retirees, were sprouting like bamboo shoots in the spring. (7) Bo, a highprofile princeling (a reference to the offspring of party elders), asked all residents to learn by heart 36 Maoist-era "revolutionary songs." Radio and TV stations nationwide broadcast these "red ditties" - which lauded the largerthan-life exploits of national heroes and "proletariat paragons" - at regular intervals. ${ }^{(8)}$ The 62 -year-old Bo was also adept at using the new media to spread his "red" messages. He often asked his assistants to text-message sayings by Mao to the city's Netizens. Bo's favourite Mao quotations included: "The world is ours; we must all take part in running [public] affairs"; "Human beings need to have [a revolutionary] spirit"; "The world belongs to young people. They are like the sun at eight or nine in the morning"; and "Once the political line has been settled, [the quality of] cadres is the deciding factor." (9) The Cultural Revolution-era practice of dispatching students to the countryside to "learn from the masses" was revived, first in Chongqing and then in other cities. Nationwide, millions of Chinese flocked to "revolutionary bases" such as Yan'an, Jinggangshan, and Shaoshan, the birthplace of the Great Helmsman. ${ }^{(10)}$

Most importantly, the re-hoisting of Maoist standards has signified a conservative turn in Chinese statecraft. Repeated appeals have been made by ideological and propaganda departments to Party members and college students to steep themselves in the works of Mao and the related Marxist canon. Such exhortations are much more emphatically made than, for example, similar calls issued by ex-president jiang Zemin during his so-called san jiang or "Three Emphases" campaign in the early

5. Cited in "Biggest Mao Zedong statue unveiled in China: Report," Agence France Presse, 26 October 2006, www.sinodaily.com/reports/Biggest_Mao_Zedong_statue_unveiled_in_China_report_999 .html (consulted on 3 March 2012).

6. Cited in "Crowds celebrating the PRC's 60th birthday surprised to see the slogan 'Long Live Mao Zedong Thought'," Forum.Xinhuanet.com, 28 September 2009, http://forum.home.news.cn/ thread/70661938/1.html (consulted on 3 March 2012). For a discussion of the erection of Mao statues and other symbols of Maoism, see, for example, Li Jing, "The legacy of Chairman Mao," China Daily, 31 July 2011, www.chinadaily.com.cn/china/2011-07/31/content_13017541.htm (consulted on 3 March 2012).

7. For a discussion of the "red songs" campaign, see, for example, Brice Pedroletti, "China sings the old red songs again," The Guardian, 9 August 2011, www.guardian.co.uk (accessible on 8 May 2012 at www.ongo.com/preview_article.php?a=1566824). See also Barbara Demick, "'Red song' campaign in China strikes some false notes," Los Angeles Times, 3 June 2011, http://articles.latimes.com/2011/jun/03/world/la-fg-china-red-20110604 (consulted on 3 March 2012).

8. See Lan Shiqiu, "Chongqing asks all citizens to sing and to pass along 36 red songs," Chongqing Daily, 20 April 2011, http://politics.people.com.cn/GB/14562/14432278.html (consulted on 3 March 2012). Brice Pedroletti, "China sings the old red songs again," The Guardian, art. cit.

9. For a discussion of how Bo popularised Mao quotes by using text messages, see, for example, Hong Xuefeng, "Bo Xilai has sent out his first red text message," People's Daily Online, 29 April 2009, http://politics.people.com.cn/GB/113795/9216543.html (consulted on 3 March 2012).

10. Cited in Jessie Jiang, "Party Time: China Pushes 'Red Tourism'," Time Asia Edition, 30 August 2011, www.time.com/time/world/article/0,8599,2090876,00.html (consulted on 3 March 2012). 
1990s. ${ }^{(11)}$ As the following sections will make clear, the CCP leadership has been reviving with gusto many values and policies that are unmistakably Maoist in nature.

\section{The meaning of the Maoist revival and changhong movement}

What exactly lies behind the Maoist resurgence? "Some people say we are going 'left,' and that we are returning to the period of the 'Cultural Revolution,", Bo said in mid-2011. "This is totally groundless." (12) According to the Deputy Director of the CCP Propaganda Department, Wang Xiaohui, changhong and related rituals "have nothing to do with the national ideology and psyche moving to the left or to the right." Wang claimed that while changhong activities proved to be popular, there were also large numbers of Chinese who favoured popular music and even rock and roll. ${ }^{(13)}$ The reality, however, is that there was a self-conscious effort by the CCP authorities to introduce policies that will do the Great Helmsman - and his fervent fans - proud.

\section{A paean to patriotism - and loyalty to CCP orthodoxy}

At the very least, the Maoist revival is a salvo toward promoting "spiritual civilisation," a concept that was raised by Deng Xiaoping to counter the materialism that would come in the wake of the country's market reforms and accumulation of wealth. As then-Party secretary Bo said, "Singing the praise of 'redness' means supporting what is right." "A city must do a good job of nurturing spiritual civilisation," he added. Bo indicated that cadres who are obsessed with GDP rates - but who lack spiritual values - may "go down the road of corruption and degeneration." (14) For most Chinese ideologues and officials, a key part of spiritual civilisation is stirring up patriotic - nationalistic - pride. As Bo put it, changhong is equivalent to "a theoretical foundation for finding one's roots in history, the return of ideals, the revival of [the Chinese] race, and the rise of the nation." (15) And since, according to long-standing orthodoxy, it is the CCP that has made possible the advancement of China, changhong also means singing the praises of the CCP.

Apart from changhong, aficionados also "read [red classics], tell [red] stories, and pass along [orthodox] axioms." Again according to Bo, most of these songs, classics, stories, and axioms have to do with "saving the country [from the brink of collapse], nation-building, and constructing a strong and prosperous China." (16) Songs featured in changhong concerts nationwide included well-known ditties popularised during the anti-Japanese war of 1937-1945, as well as songs from the 1950s and 1960s. Among them were March of the Volunteers (which doubles as the national anthem); March of the Big Knives and Protecting the Yellow River (both anti-Japanese songs); Sing a Song about the Motherland, Song of Lei Feng, and the more contemporary My Chinese Heart. Very often the singing sessions ended with the de rigueur There Won't Be a New China Without the Chinese Communist Party. (17) "When we sing My Chinese Heart, we are demonstrating the cohesiveness, the centripetal tendency of the Chinese race," Bo noted. "We must unambiguously uphold artistic works that can hold tight the hearts of the people, and that are healthy and righteous." (18)

"Revolutionary tourism" - which is yet another offshoot of the revitalisation of Maoism - also carries immense symbolic significance. According to Vice-President Xi, who has toured most of the "red" shrines in provinces including Hunan, Jiangxi, and Shaanxi, meccas like Shaoshan, the birthplace of Mao, are "resources of revolutionary tradition" and "valuable spiritual treasures of our party." "Red tourist spots are a vivid classroom for studying the tradition and learning new things," he said while touring Shaoshan in early 2011. "They contain rich political wisdom and moral nutrients." (19) Even though Bo's "red campaign" never got any official imprimatur from top central Party organs such as the Politburo or its Standing Committee, a number of Politburo Standing Committee (PBSC) and Politburo members began visiting Chongqing in the second half of 2010 to show their support for this conservative crusade. These top cadres included Wu Bangguo, Zhou Yongkang, Xi Jinping, and Li Yuanchao. The official Xinhua News Agency quoted Vice-President Xi, who toured Chongqing in December 2010, as "affirming the practice of singing red songs and studying [Maoist] classics... as a means of pursuing education in [Marxist] ideals and beliefs." (20) Li, who is a Politburo member and Director of the CCP Organisation Department, did not give an excessively ideological interpretation of the changhong fad during his trip to Chongqing. He nevertheless agreed that reinstating the "red" tradition was a laudatory patriotic experience. While in Chongqing in April 2011, Li joined Bo in a changhong concert. Li said that changhong activities were "conducive to propagating a [morally] uplifting social atmosphere." "A large quantity of 'people's songs' that reflected the heart and soul of the people emerged during the times of the revolution, the war, and the construction of the New China," Li said. "We must all sing these good songs together." (21) Given that Li is a protégé of President Hu and a senior member of the supremo's Communist Youth League Faction, this was clear-cut proof that many of the values behind Bo's Maoism-related activities were shared by other cliques in the CCP.

Indeed, many Chinese remember Mao as the larger-than-life founder of the Republic and the "pride of the Chinese race." The contributions of Mao were played up in the blockbuster movie The Founding of a Republic, which was specially commissioned by Party authorities to celebrate the $60^{\text {th }}$ anniversary of the establishment of the People's Republic of China. ${ }^{(22)}$ Central Party

11. For a discussion of the san jiang or "Three Emphases" Campaign ("emphasis on studying [the Marxist canon], on politics, and on righteousness"), which Jiang Zemin started in 1995, see "Jiang Zemin: Putting emphasis on studies, on politics and on righteousness (1995)," www.BKPCN.com, 25 December 2008, http://cpc.people.com.cn/GB/33837/2535045.html (consulted on 3 March 2012). It should be noted, however, that when Jiang asked Party members to study the Marxist canon, there was no specific effort to revive Maoist norms and practices.

12. "Bo Xilai: Changhong doesn't mean a return to the Cultural Revolution,"Chongqing Daily, 30 June 2011, http://news.wenweipo.com/2011/07/01/IN1107010056.htm (consulted on 3 March 2012).

13. "The Propaganda Department: Changhong has nothing to do with a leftward or rightward shift in ideology," China News Service, 23 June 2011, www.chinanews.com/gn/2011/06-23/31321 23.shtml (consulted on 3 March 2012).

14. Citing Bo's views on the values of "spirit," see, for example, "Bo Xilai: We want the law of prices but we also require the [human] spirit," Chongqing Daily, 27 October 2010, http://forum.home. news.cn/detail/79659526/1.html (consulted on 3 March 2012).

15. Cited in Yang Fan, "Commentary on the Chongqing model - The biggest controversy in China in the past two years," in www.wyzxsx.com, 1 January 2011, www.wyzxsx.com/Article/Class4/ 201101/206595.html (accessible on 8 May 2012 at www.tqohw.com/mrdjh/1869.html).

16. For a discussion of the contents of the "red songs," see, for example, "Why are red songs red: Use a tolerant attitude to look at a specific manifestation of the times," China News Service, 6 June 2011, www.chinanews.com/cul/2011/06-06/3091459.shtml (consulted on 3 March 2012).

17. Cited in "Bo Xilai and Huang Qifan meet the domestic and foreign media," Chongqing Daily, 8 March 2011, http://cq.99.com/a/20110308/000005.htm (consulted on 3 March 2012).

18. Cited in "Bo Xilai: A great people must have lofty cultural pursuits," Chongqing Daily, 1 July 2011, www.cnnz.gov.cn/bbxq_content/2011-07/01/content_1507024.htm (consulted on 3 March 2012).

19. Cited in "Xi Jinping visits and conducts research at Shaoshan, Hunan Province," China News Service, 23 March 2011, www.chinanews.com/gn/2011/03-23/2926435.shtml (consulted on 3 March 2012).

20. See "Xi Jinping affirms changhong activities in Chongqing," Xinhua News Agency, 12 August 2011, http://china.huanqiu.com/roll/2010-12/1327317.html (consulted on 3 March 2012).

21. "LiYuanchao: Chongqing's reforms have provided a new way of thinking for solving China's difficult problems," Chongqing Daily, 16 April 2011, www.chinanews.com/gn/2011/04-19/2981427.shtml (consulted on 3 March 2012).

22. For an explication of the significance of the film The Founding of a Republic, see, for example, "Star-studded blockbuster The Founding of a Republic," CCTV, 14 September 2009, www.china.org.cn/video/2009-09/14/content_18585357.htm (consulted on 3 March 2012). 
School theorist Li Junru, who first gained fame for his exposition of Deng's reform programs, characterised Mao as a titan who "led the Chinese people in their struggle against the reactionary rule of imperialism and feudalism, so that the Chinese race [could] stand tall among the people of the world." (23) Moreover, according to conservative theoretician Peng Xiaoguang, the enduring enthusiasm for Mao Zedong Thought, particularly among the young, testified to the intelligentsia's search for an "ultimate faith that could speed up China's rise in the wake of the global financial crisis." (24)

It was Zhang Quanjing, a former Director of the CCP Organisation Department, who perhaps gave the most eloquent explanation of the relevance of Maoism to twenty-first century China. In a 2011 article entitled "We Must Unswervingly Continue to Uphold Mao Thought," Zhang said the Great Helmsman's ideas consisted of the "paradigm of synthesising Marxism-Leninism and revolution and construction in China." "Mao Thought has incorporated the wisdom of China and the world during different historical periods," Zhang asserted. In areas including ideology, military affairs, politics, economics, culture, technology, and sports, the ideologue indicated, Maoism was "the crystallisation of the intelligence of the whole party and all Chinese." (25)

\section{Celebrating red GDP and egalitarianism}

There is also a "materialistic" side to the Maoist revival: a re-emphasis on the values of egalitarianism and social equality that a sizeable sector of the population associates with the Maoist era. This was also a reaction to the increasing polarisation of rich and poor - and the increasing stratification of Chinese society based on money and privilege - that was regarded as a result of 30-odd years of Deng Xiaoping-style reform. The spectre of "class antagonism" was exacerbated by Jiang Zemin's decision in 2001 to allow private entrepreneurs, professionals, and members of the middle-classes into the CCP. This has resulted in the social downgrading of the "lower classes" of workers and peasants, who used to be pillars of the Party. (26)

One of the key factors behind the so-called "scientific theory of development" of the Hu-Wen administration is to rectify many of the ill effects of Deng and Jiang's policies. There is significant measure of neo-Maoism behind such of Hu's slogans as "putting people first." By the late 2000s, however, it had become clear that the rich-poor gap - as well as the discrepancies between east and west China - was yawning wider and wider. ${ }^{(27)}$ Bo apparently seized the opportunity to revive a kind of crypto-Maoist "red GDP," a supposedly non-exploitative growth model that would be populist and, in a way, egalitarian. As Bo put it: "The most important basis of a harmonious society is [winning] the hearts of the people." "It's not enough to win the support of 10 percent or 15 percent of the people; we have to let more than 90 percent of the people feel satisfied," he noted. (28)

Red GDP is a codeword for economic development that is geared toward the needs of the masses - and not dictated by the greed of privileged classes such as the country's estimated 30 million millionaires. (29) For example, while real estate prices in cities ranging from Shanghai to Shenzhen were going through the roof, Chongqing cadres pledged to ensure that at least one third of all apartments in the metropolis were affordable to workers and farmers. For instance, Chongqing has been hailed as a pioneer in providing so-called "social security housing," - or subsidised flats for the lower classes. ${ }^{(30)}$ This idea was picked up in the $12^{\text {th }}$ Five Year Plan (2011 to 2015), in which the Wen cabinet pledged that more than 36 million units of social security housing would be provided nationwide during these five years. ${ }^{(31)}$

Chongqing has also attracted nationwide attention for its experiment in the partial solution of the hukou (residence permit) system - which has since the 1950s prevented rural-born Chinese from moving to and settling in the cities. Urban-rural segregation is set to be abolished within the municipality by the mid-2010s, when all Chongqing residents can live and work within the confines of the municipality. ${ }^{(32)}$ Yet Bo's most attention-grabbing policy was his crusade against the triads (or Chinese mafia) - the so-called dahei ("strike the dark forces") campaign - in 2009. Within a period of six months, Chongqing police arrested 24 big-time crime bosses, who coughed up 1.7 billion yuan of ill-gotten gains. In addition, more than 200 mid-tohigh-ranking officials in Chongqing's law-enforcement and judicial departments were nabbed for taking bribes from criminals. These bad apples included the former head of the Chongqing Judicial Bureau, Wen Qiang. Wen, who is also a former police chief, admitted to taking bribes and gifts totalling nearly 100 million yuan. ${ }^{(33)}$

In addition, Bo sought to placate the petitioners - "lower-class" Chinese who want to present senior officials with their grievances - by asking some 200,000 municipal employees to regularly meet with residents who claim to be victims of bureaucratic and other forms of injustices. ${ }^{(34)}$ Bo and the Chongqing mayor, the master bureaucratic fixer Huang Qifan, indicated that the key to the CCP maintaining its perennial ruling-party status was "whether it is tightly linked with the people and the masses." "Chairman Mao put it best: we must serve the people with all our hearts and minds," Bo noted. "The party will become impregnable if cadres from top to bottom are tightly bonded with the masses" (35)

There are critics galore, however, who think that Bo's so-called red GDP concept is but a regurgitation of bits and pieces of the Hu-Wen adminis-

23. Li Junru, "Mao Zedong, the people's hero," People's Daily, 23 October 2009, http://theory.people. com.cn/GB/10242116.html (consulted on 3 March 2012).

24. Cited in Willy Lam, "Power struggle behind revival of Maoism," Asia Times, 24 November 2009, www.atimes.com/atimes/China/KK24Ad01.html (consulted on 3 March 2012).

25. Zhang Quanjing, "We must unswervingly continue to uphold Mao Thought," People's Daily, 30 March 2011, http://theory.people.com.cn/GB/11253085.html (consulted on 3 March 2012).

26. For a discussion of how Jiang Zemin's "Theory of the Three Represents" has exacerbated "class differences" in Chinese society, see, for example, Willy Lam, Chinese Politics in the Hu Jintao Era, New York, M E Sharpe, 2006, pp. 65-68.

27. For a discussion of the growing rich-poor gap in China, see, for example, Dexter Roberts, "China's growing income gap," Businessweek, 27 January 2011, www.businessweek.com/magazine/content/11_06/b4214013648109.htm (consulted on 3 March 2012); Chris Buckley, "Is Wen's 'new socialist countryside' working?", Reuters, 22 February 2011, www.reuters.com/article/2011/02/22/ us-china-labour-rural-idUSTRE71L1EN20110222 (consulted on 3 March 2012).

28. "Bo Xilai: 'The most important basis of a harmonious society is winning the hearts of the people'," Chongqing Evening Post, 19 August 2011, http://news.xinhuanet.com/local/2011-08/19/c_ 121880571.htm (consulted on 3 March 2012).

29. For a discussion of the "Red GDP phenomenon," see, for example, Ji Shiming, "In search of the red GDP whirlwind in Chongqing," Yazhou Zhoukan (Asia Weekly), Hong Kong, 6 November 2009, http://wen.org.cn/modules/article/view.article.php/1711 (consulted on 3 March 2012).

30. For a discussion of low-cost housing in Chongqing, see, for example, "Chongqing will overfulfil its quota of social-security housing by the year 2015," Chongqing Daily, 6 June 2011, www.cq.gov.cn/today/news/321076.htm (consulted on 3 March 2012).

31. Cited in "China promises 4 million units of affordable housing in 2011," People's Daily (English edition), 13 July 2011, http://english.people.com.cn/90001/90778/90862/7439066.html (consulted on 3 March 2012). Also see "China speeds up low-rent housing," China.org.cn, 17 March 2011, www.china.org.cn/china/2011-03/17/content_22159081.htm (consulted on 3 March 2012).

32. For a discussion of the hukou reforms in Chongqing, see, for example, Cui Zhiyuan, "Chongqing's innovation in hukou reforms," Expo2010.cn, 10 September 2010, www.expo2010.cn/a/ 20100910/000025.htm (consulted on 3 March 2012).

33. For a discussion of the anti-triad operations in Chongqing, see, for example, Jaime FlorCruz, "China cracks down on Chongqing's gangsters," CNN, 21 October 2009, http://articles.cnn.com/200910-21/world/china.corruption_1_chongqing-drug-trafficking-corruption?_s=PM:WORLD (consulted on 3 March 2012); Geoff Dyer, "China executes former Chongqing official," 7 July 2010, www.ft.com/intl/cms/s/0/48180956-898a-11df-9ea6-00144feab49a.html\#axzz1WfQBGUEm (consulted on 3 March 2012).

34. Cited in "Bo Xilai and Huang Qifan meet the domestic and foreign media," op. cit.

35. "Bo Xilai proposes building a moral high ground in Chongqing," Chongqing Morning Post, 25 July 2011, www.chinanews.com/gn/2011/07-25/3205619.shtml (consulted on 3 March 2012). 
tration's "scientific theory of development." Several central and provincial cadres had as early as 2008 propagated concepts including "attaining GDP without blood" or "green GDP." (36) Appeals to a more egalitarian society have also repeatedly been made by Premier Wen, who said famously at a National People's Congress (NPC) conference in 2010 that "social equality and justice should shine even brighter than the sun." Moreover, one of the earlier pioneers of social-security housing was PBSC member and Hu Jintao protégé Li Keqiang when he was Party Secretary of Liaoning Province from 2004 to 2007. (37) Ironically, Bo had neglected the issue of housing for the poor when he was governor of Liaoning from 2001 to 2004. However, the charismatic princeling's ability to generate publicity - and to garner plaudits - by repackaging others' ideas as his own certainly testified to his political skills. This also demonstrates that talk about egalitarianism and social justice by the crypto-Maoists was often a public-relations exercise geared toward boosting the political fortunes of individual cadres.

\section{Deeper-level factors behind the Maoist revival}

On a deeper level, the quasi-Maoist renaissance is a political movement undertaken by the CCP leadership to uphold political stability and weed out challenges to the regime. Factional dynamics is also involved. The Party's much-attenuated liberal wing - which consists of the remnant followers of the late titans Hu Yaobang and Zhao Ziyang - has been dealt a body blow. And the taizidang, or Gang of Princelings, of which Bo is a well-known leader, is cynically using the changhong crusade to enhance the political fortunes of cadres with "revolutionary bloodlines."

\section{The mainstream factions' views about the Maoist restoration}

A perennial problem for the post-Cultural Revolution mainstream ruling factions - including the Deng Xiaoping Faction, the Shanghai Faction led by ex-president Jiang Zemin, and the Communist Youth League (CYL) Faction headed by President $\mathrm{Hu}$ Jintao - is how to strike a balance between leftists (ultra-radical crypto-Maoists) on the one hand, and rightists (pro-West liberals) on the other. The leftists fully acknowledge the precept of one-party dictatorship under the CCP, but they are opposed to market-oriented reforms begun by Deng Xiaoping in the late 1970s - and followed by Jiang Zemin and Hu Jintao - especially privatisation and China's integration with the global marketplace. Leftists, who are also called the New Leftists, have also laid into the unholy alliance between senior Party cadres and big business, which has resulted in the emergence of super-rich clans within the Party's upper echelons. ${ }^{(38)}$ Being successors of Hu Yaobang and Zhao Ziyang, rightists advocate no-holds-barred adoption of international values, including Western-style political reforms. At least in the eyes of pro-status quo leaders ranging from Deng Xiaoping to $\mathrm{Hu}$ Jintao, the rightists' hidden agenda is to emulate Mikhail Gorbachev by "changing the nature of the party" through political liberalisation. ${ }^{(39)}$

For leaders including Deng, Jiang, and Hu, leftists or Maoists are considerably easier to handle than rightists. The rule of thumb is to ignore the neoMaoists' criticisms of market reforms as well as capitalist-style corruption. However, aspects of Maoism that dovetail with the goals of the regime especially the glorification of nationalism as well as national heroes such as Mao - have been incorporated into the Hu leadership's programs of promoting stability through means such as slamming dissidents who support the "rightist" goals of political liberalisation. ${ }^{(40)}$ Thus, even though President Hu has up to mid-2012 never made any pronouncement on the changhong movement, he and his Politburo allies are happily tailoring the Maoist campaign to their particular needs. The latter include hitting out at dissidents such as Liu Xiaobo and Ai Weiwei in addition to members of the CCP's remnant liberal faction. ${ }^{(41)}$

\section{Weeding out "bourgeois-liberal" values and imposing tighter ideological control}

Irrespective of the controversial reputation of Mao Zedong, Maoism represents Communist Party orthodoxy, the sacrosanct heirlooms of the CCP's 90-year struggle to become not only China's "perennial ruling party" but also the largest and most powerful political party in the world. Playing up Maoism is a handy way for the CCP leadership to prevent the spread of "bourgeois-liberal,"Westernised - and potentially destabilising - values. This is particularly significant in light of the fact that beginning with the riots in Tibet and neighbouring provinces in March 2008, "anti-Beijing" sentiments and activities have been on the increase. In 2010, there were an estimated 180,000 counts of "mass incidents," a euphemism for riots, disturbances, and other instances of social unrest. ${ }^{(42)}$ The "colour revolutions" that began in Tunisia and Egypt in early 2011 raised the spectre of a "Jasmine Revolution" that might one day sweep the CCP into the dustbin of history. ${ }^{(43)}$

From 2008 onwards, the Hu-led Politburo began to underscore the imperative of a yiyuanhua (one-dimensional or "monolithic") guiding principle in ideology and policies of state. This was made clear by President Hu's speech in December 2008 marking the $30^{\text {th }}$ anniversary of the start of the

36. Regional cadres such as Guangdong Party Secretary Wang Yang and Shanxi Party Secretary Zhang Baoshun indicated as early as 2008 that they did not want to achieve "GDP that is tainted with blood." See, for example, "Zhang Baoshun:We resolutely do not want GDP that is tainted with pollution and blood," People's Daily Internet Edition, 17 October 2010, http://leaders. people.com.cn/GB/8188892.html (consulted on 3 March 2012).

37. For a discussion of the clearing up of squatters in Liaoning, see, for example, "Liaoning's 'No. 1 people's livelihood project' allows 1.55 million people to say goodbye to squatters' area," CNTV.cn, 11 January 2011, http://news.cntv.cn/20110111/100943.shtml (consulted on 3 March 2012); "Li Keqiang: 'Let's save on other expenses so as to transform the squatters' district,', Xinhua News Agency, 12 March 2006, www.xinhuanet.com/chinanews/2006-03/12/content_6446248.htm (consulted on 3 March 2012); See also "Wen Jiabao meets the foreign media," Xinhua News Agency, 14 March 2011, http://news.xinhuanet.com/politics/2010-03/14/content_13169432.htm (consulted on 3 March 2012).

38. For a discussion of China's "New Left," see, for example, Ariana Eunjung Cha, "For China's new left, old values," The Washington Post, 19 April 2009, www.washingtonpost.com/wp-dyn/content/article/2009/04/18/AR2009041801939.html (consulted on 3 March 2012); also see Pankaj Mishra, "China's new leftist," The New York Times, 15 October 2006, www.nytimes.com/2006/10/15/magazine/15leftist.html (consulted on 3 March 2012).

39. For a discussion of the CCP leadership's attitude toward "rightists," see, for example, Jian Jubo, "China at a crossroad: Right or left?" Asia Times, 24 April 2009 www.atimes.com/ atimes/China/KD24Ad01.html (consulted on 3 March 2012).

40. For a discussion of the Hu leadership's measures to uphold political stability, see, for example, Willy Lam, "Beijing's blueprint for tackling mass incidents and social management," China Brief, 25 March 2011, www.jamestown.org/single/?no_cache=1\&tx_ttnews\%5Btt_news\%5D=37696 (consulted on 3 March 2012).

41. For a discussion of Beijing's treatment of dissidents in 2010 and 2011, see, for example, Ariel Zirulnick, "Five famous jailed dissidents in China: AiWeiwei to Liu Xiaobo," Christian Science Monitor, 12 April 2011, www.csmonitor.com/World/Asia-Pacific/2011/0412/Five-famous-jailed-dissidentsin-China-Ai-Weiwei-to-Liu-Xiaobo/Ai-Weiwei (consulted on 3 March 2012); so also, Ku Yang, "Beijing Intensifies Pressure as Jasmine Smile Hits China," Human Rights in China (New York) Briefing, www.hrichina.org/crf/article/5420 (consulted on 3 March 2012).

42. Cited in "China's spending on internal police force in 2010 outstrips defense budget," Bloomberg News, 6 March 2011, www.bloomberg.com/news/2011-03-06/china-s-spending-on-internal-police-force-in-2010-outstrips-defense-budget.html (consulted on 3 March 2012).

43. For a discussion of authorities' tactics toward a possible "Jasmine Revolution," see, for example, lan Johnson, "Calls for a 'Jasmine Revolution' in China persist," The New York Times, 23 February 2011, www.nytimes.com/2011/02/24/world/asia/24china.html (consulted on 3 March 2012); also see Chris Hogg, "China's security tsar warns over 'Jasmine revolution'," BBC news, 21 February 2011, www.bbc.co.uk/news/world-asia-pacific-12522856 (consulted on 3 March 2012). 
Era of Reform. The supremo vowed that the CCP would uphold the "Four Cardinal Principles" of stern party control - and that the government would do whatever it took to "boost its ability to guard against changes [to a capitalist system] and to withstand risks" such as socio-political instability. Hu also delivered a stern warning to liberal cadres who favoured the adoption of at least some form of international values such as elections and the rule of law. The CCP, he said, "will never take the deviant path of changing the flag and standard [of party orthodoxy]." (44)

Hu's message has been repeated by top officials such as NPC Chairman Wu Bangguo and Chen Kuiyuan of the Chinese Academy of Social Sciences (CASS). In March 2011, Wu shocked even Chinese intellectuals by enunciating his "Five Nos" principle, including the fact that the CCP would never "undertake the diversification of [the Party's] guiding principle." ${ }^{(45)}$ In a major article released at about the same time, CASS's Chen pointed out that the CCP and all Chinese can only follow one principle: Marxism. All CCP members must "believe in Marxism and be resolute Marxists," he said. "Both the party charter and the Constitution have clearly stipulated that Marxist theory is the theoretical basis of the guiding principle of our party and state," he said. "Marxism," of course, is an omnibus term that incorporates allied creeds such as Leninism and Mao Zedong Thought, all of which are part of the sacrosanct "Four Cardinal Principles." As Chen said, "we have to study the theoretical system of socialism with Chinese characteristics; we have to synthesise the study of Marxism, Leninism, and Mao Zedong Thought." (46)

Supremo-in-waiting Xi Jinping (who is the son of former vice-premier Xi Zhongxun) has also played a sizeable role in the propagation of the yiyuanhua or monolithic approach to ideology. Since becoming President of the CCP Central Party School (CCPCPS) in 2007, he has been stepping up oldstyle Marxist - and Maoist - indoctrination. For example, at the opening of a CPS semester in April 2011, Xi urged students to "pay attention to the Marxist canon," especially Mao's classic writings. "Cadres must seriously study Marxist theory to ensure that they can maintain political resoluteness," he said. Xi added that since Marxist classics were voluminous, "We should focus on the salient points, and concentrate on studying the quintessence - particularly the important works of Mao Zedong." (47)

Indeed, the heir-apparent to Hu likes to sprinkle his homilies to CCPCPS students with Mao's words of wisdom. Xi's repeated emphasis on recruiting and grooming neophytes who are "both politically upright and professionally competent" echoes Mao's dictum on picking officials who are "both red and expert." While talking about "party construction," or ways to ensure the ideological purity of CCP cells, Xi noted that the leadership must learn from the "great party-construction engineering project that was successfully pioneered by the First-Generation leadership with comrade Mao Zedong as its core" (48) When he was touring the provinces, Xi liked to celebrate "proletariat paragons" first lionised by Chairman Mao. Thus, while inspecting the Daqing Oilfield in Heilongjiang Province in late 2009, the vice-president eulogised the "spirit of the Iron Man of Daqing," a reference to the well-nigh super-human exploits of Wang Jinxi, the legendary oilfield worker. Xi has also heaped praise on "heroes of the masses" such as the self-sacrificing fire fighter Lei Feng and the altruistic county Party secretary Jiao Yulu. ${ }^{(49)}$

While Hu seldom talks about Maoism, he has been vigorously propagating strait-laced orthodoxy and uniformity of thought through the campaign of "Sinicising and popularising Marxism." As far back as 2006, Hu earmarked more than $\$ 10$ million to set up a new Marxism-Leninism Academy. Its function was to churn out up-to-date - and Sinicised - works of Marxism. ${ }^{(50)}$ At a 2010 forum on "promoting popular contemporary Chinese Marxism,"
Director of the CCP Propaganda Department Liu Yunshan pointed out that cadres should "deeply grasp the laws of Marxist development, and better arm the entire party - and educate the people - with the theoretical system of Chinese socialism." "We must take hold of the people through better [use of] the latest fruits of the Sinicisation of Marxism," said Liu, a conservative commissar who often acts as Hu's spokesman. ${ }^{(51)}$

\section{Using Maoism to hit out at "rightist" intellectuals}

The Maoist campaign has also constituted a potent attack on efforts by the Party's much-weakened liberal faction - and intellectuals in general to spread Western or international values. It is not surprising that Wen Dao and Ning Yunhua, both frequent contributors to the leftist Utopia website (wyzxsx.com), ${ }^{(52)}$ the Maoist camp's main Net vehicle, characterised the changhong campaign thus: "These red songs, soaked with the bright red blood of revolutionary martyrs, are the spiritual medicine people need to free themselves of the poison of Western class society and spiritual opium." (53)

The partial restoration of Maoist practices has thrown light on the perennial struggle between crypto-Maoist conservatives and pro-West intellectuals. Take, for example, the ferocious ideological battle between a group of liberal intellectuals led by Mao Yushi and Xin Ziling on the one hand, and the New Left, or quasi-Maoists, represented by the Utopia website on the other. Xin, a rebel intellectual who served in the PLA, published his The Fall of the Red Sun in early 2011. The book, which chronicled Mao's horrendous blunders, is in some ways comparable to the best-selling tome Mao, the Untold Story written by Jung Chang and Jon Halliday. ${ }^{(54)}$ In his review of Red Sun, the well-known economist Mao Yushi (not related to the Great Helmsman) wrote: "Since [Mao] was not a god, he will be removed from the altar, divested of all the myth that used to shroud him, and receive a just evaluation as an ordinary human being." (55)

44. "Hu Jintao's speech at the Meeting Marking the 30th Anniversary of Reform and Opening Up," China.org.cn, 18 December 2008, www.china.org.cn/archive/2009-05/11/content_17753659.htm (consulted on 3 March 2012).

45. Cited in Michael Bristow, "Chinese leader rules out democracy," BBC news, 10 March 2011, www.bbc.co.uk/news/world-asia-pacific-12697997 (consulted on 3 March 2012).

46. Chen Kuiyuan, "Have faith in Marxism, and become a resolute Marxist," People's Daily, 29 April 2011, http://theory.people.com.cn/GB/14513063.html (consulted on 3 March 2012).

47. Li Zhangjun, "Xi Jinping talks about attaching importance to classic works during ceremony to mark new semester at the Central Party School," People's Daily, 14 May 2011, http://politics.people.com.cn/GB/1024/14635203.html (consulted on 3 March 2012).

48. Cited in Xi linping, "Looking back and thinking about party construction in the past 30 years of reform," China.com.cn, 8 September 2008, www.china.com.cn/policy/txt/200809/08/content_16410998.htm (consulted on 3 March 2012).

49. Cited in Willy Lam, "The CCP's disturbing revival of Maoism," China Brief, Jamestown Foundation, Washington, DC, 19 November 2009, www.jamestown.org/programs/chinabrief/single/ ?tx_ttnews\%5Btt_news\%5D=35746\&cHash=2097a3de2c (consulted on 3 March 2012).

50. Cited in Jane Macartney, "China plans to profit from Marx," The Times of London, 3 January 2006, www.timesonline.co.uk (accessible on 8 May 2012 at http://groups.yahoo.com/group/ chinalist/message/179).

51. Liu Yunshan, "Use the newest products of the Sinicisation of Marxism to take hold of the masses," People's Daily, 29 March 2010, http://news.xinhuanet.com/politics/2010-03/29/content_ 13265766.htm (consulted on 3 March 2012).

52. The website Utopia was closed down in early April following the removal of Bo Xilai from his post. See "China shuts down Maoist website Utopia," The Guardian, 6 April 2012, http://www. guardian.co.uk/world/2012/apr/06/china-maoist-website-utopia (consulted on 8 May 2012).

53. Cited in Wen Dao and Ning Yunhua, "The campaign of singing red songs and targeting the triads has won the people's hearts," www.wyzxsx.com, 8 May 2011, www.wyzxsx.com/ Article/Class22/201105/232673.html (no more available at time of editing).

54. Cited in Didi Kirsten Tatlow, "Mao's Legacy Still Divides China," The New York Times, 5 May 2011, www.nytimes.com/2011/05/06/world/asia/06iht-letter06.html (consulted on 3 March 2012).

55. Ibid.; see also Ed Zhang, "Rising resentment at the mass campaign to spread red songs," South China Morning Post, 3 July 2011. 
Peking University's He Weifang, an internationally famous legal scholar and human rights activist, has thrown his support behind the de-Maoification movement. In a series of articles in 2010 and 2011, Professor $\mathrm{He}$ pointed out that the "new China" built by Mao "has inherited the trappings of feudalism." "The unlimited power of the deified leader has exceeded even that of dynastic emperors," He wrote, adding that "the totalitarian control over the spirit and thoughts was the most classic" example of Maoist tyranny. While talking about the Cultural Revolution, Professor He indicated that Chinese must raise their guard against recent efforts to revive Mao's authority. "Chinese ignorance about the Cultural Revolution and efforts by certain political forces to exploit this ignorance has constituted a barrier to the deepening of China's reform and opening up." (56)

Xin and Mao's call for ending a Mao-style personality cult drove Maoists into a rage. On Wyzxsx.com and other conservative forums, Mao Yushi was labelled a "capitalist running dog," a "cow ghost" and a "snake demon." One New Left group even collected 10,000 signatures to support its demand that police arrest the liberal economist for alleged subversion and libel. ${ }^{(57)}$ While the police and state-security apparatus are unlikely to go after opponents to the reinvigoration of Maoist values, the authorities are more than happy to let leftist forces put pressure on progressive intellectuals represented by Mao Yushi and Xin.

It is also significant that figures such as Mao Yushi and Xin represent the CCP's remnant liberal wing - followers of Hu Yaobang and Zhao Ziyang who suffered a devastating blow in the wake of the 4 June 1989 massacre. Fighting the Mao-style personality cult is but part of the liberals' agenda: their main goal is to introduce internationally recognised political norms, including multi-party politics, and freedom of the media and religion. The outbursts of Mao Yushi and Xin were the latest manifestations of a line of thinking that started with such illustrious contemporaries of Hu Yaobang as deputy People's Daily editor Wang Ruoshui and theorist Li Honglin. ${ }^{(58)}$ Wang, author of the much-claimed The Newly Discovered Mao Zedong, was the first intellectual who dared propose that Mao's portrait be removed from the rostrum of Tiananmen Square. In the early days of Deng's reform, Li gave a vastly influential internal speech entitled "Leaders and the People," in which the avant-garde theorist castigated the mentality behind Mao worship. "It is not true that the people should be loyal to leaders; leaders should be loyal to the people," he said. ${ }^{(59)}$

Among senior cadres, Premier Wen Jiabao is considered by a sizeable number of intellectuals to be a keen proponent of political reform - as well as international norms. In an article that he wrote for the Xinhua News Agency in early 2007, Premier Wen openly pressed for the adoption of pushi jiazhi, or "universal values." "Democracy, a [fair] legal system, freedom, human rights, egalitarianism... are not unique to capitalism," Wen indicated. "They are values that all humankind is jointly pursuing." (60) The premier continued to make propaganda for political reform during his much-noted tour of Shenzhen in the summer of 2010. Without the "guarantee" of political reform, Wen said in the special economic zone, "the fruits of the reform of the economic structure may be lost, and it will be impossible to realise the goal of modernisation." (61) It is likely that the conservatives were targeting Wen in addition to less prominent figures such as Mao Yushi.

\section{Using Maoist tactics against dissidents - and the rapid deterioration of rule of law}

Gradually but inevitably, China has taken on the traits of a police state. Human rights conditions have deteriorated even as the law-enforcement apparatus is committed to "nipping all destabilising forces in the bud." In the days of Jiang Zemin, the police and state-security personnel just locked up dissidents; in the past few years, they have even incarcerated the spouses and close relatives of public intellectuals such as Nobel Laureate Liu Xiaobo. Even after a human-rights lawyer or NGO activist such as Gao Zhicheng is released, he or she is still subject to either house arrest or 24hour surveillance. ${ }^{(62)}$ The Hu administration's determination to emasculate all potential sources of opposition, which include NCOs and the media was reflected in the budget allocated for the purpose of wei-wen or "upholding stability." In 2012, the NPC approved outlays worth US\$111.4 billion for public-security departments. In comparison, the PLA budget was only $\$ 106.5$ billion. This was the second time in a row that wei-wen expenditures exceeded those of the military. Regional wei-wen budgets for provinces and cities including Liaoning, Guangdong, Beijing, and Suzhou also went up by an annual average rate of at least 15 percent in the late 2000s. ${ }^{(63)}$

Maoism - and Mao's well-recorded penchant for mercilessly smashing all opposition - has provided perhaps the best justification for this scorchedearth policy toward dissent. It was, after all, the Great Helmsman who instituted the largest-scale pogroms against dissidents and free-thinkers - the Anti-Rightist Movement (ARM) - in the 1950s. Deng Xiaoping was a key executor of the ARM crusade, (64) and it was not surprising that when Deng rolled out the Four Cardinal Principles in the early 1980s to ensure that his economic reform would not spawn bourgeois-liberalisation, he again resorted to the Maoist tactic of imposing "the dictatorship of the proletariat" on oppositionists including Wei Jingsheng, Guo Luoji, and Liu Binyan. (65)

56. He Weifang, "On the 45 anniversary of the Outbreak of the Cultural Revolution," He Weifang's blog, 16 May 2011, www.21ccom.net/articles/lsjd/Lsjj/article_2011051735607.html (consulted on 3 March 2012).

57. Cited in Kent Ewing, "Mao's army on the attack," Asia Times (Hong Kong), 4 June 2011, www.atimes.com/atimes/China/MF04Ad01.html (consulted on 3 March 2012).

58. For a discussion of the ideas of Wang Ruoshui and his fellow liberals, see, for example, Elisabeth Rosenthal, "Wang Ruoshui, 75, liberal who was shunned in China," The New York Times, 14 January 2002, www.nytimes.com/2002/01/14/obituaries/14WANG.html (consulted on 3 March 2012); also see Bill Brugger, "From 'Revisionism' to 'Alienation,' from Great Leaps to 'Third Wave'," China Quarterly, no. 108, December 1986, pp. 643-651.

59. Cited in Li Honglin, Tianya sanyi (Three snapshots from my life), Hong Kong, Cosmos Books, 2011, p. 73.

60. Cited in Wen Jiabao, "On several questions relating to the historical tasks of the early stage of socialism and China's foreign policy," Xinhua News Agency, 26 February 2007, http://news.xinhuanet.com/politics/2007-02/26/content_5775212.htm (consulted on 3 March 2012).

61. Cited in Willy Lam, "Premier Wen's 'Southern Tour': Ideological rifts in the CCP?", China Brief, Jamestown Foundation, 10 September 2010, www.jamestown.org/single/?no_cache=1\&tx _ttnews\%5Btt_news\%5D=36809 (consulted on 3 March 2012).

62. For a discussion of the plight of blind activist Chen Guangcheng, see, for example, Andrew Jacobs, "China's intimidation of dissidents said to persist after prison," The New York Times, 17 February 2011, www.nytimes.com/2011/02/19/world/asia/19china.html?pagewanted=all (consulted on 3 March 2012)

63. Cited in "China boosts domestic security budget to face growing unrest," Mercopress.com, March 6, 2012, http://en.mercopress.com/2012/03/06/china-boosts-domestic-security-budget-to-facegrowing-unrest (consulted on 3 March 2012); See also "China internal security spending jumps past army budget," Reuters, 5 March 2011, http://mobile.reuters.com/article/idUSTO E72400920110305?ca=rdt (consulted on 3 March 2012).

64. For a discussion of Deng's role in the Anti-Rightist Movement, see, for example, "Bao Tong on the 50th anniversary of the Anti-Rightist Campaign," Radio Free Asia, 15 June 2007, www.rfaunplugged.org/2007/06/15/bao-tong-on-the-50th-anniversary-of-the-anti-rightist-campaign/ (consulted on 3 March 2012).

65. For a discussion of the CCP's treatment of liberal party members such as Liu Binyan, Wang Ruoshui, and Guo Luoji, see, for example, Merle Goldman, Sowing the Seeds of Democracy in China: Political Reform in the Deng Xiaoping Era, Cambridge (MA), Harvard University Press, 1994, pp. 62-112; also see Kalpana Misra, "Deng's China: From Post-Maoism to Post-Marxism," Economic and Political Weekly, vol. 33, no. 42/43 (17-30 October 1998), pp. 2740-2748, http://web.me.com/mconway/DPHistory/page1/page13/files/Deng\%20and\%20China.pdf (consulted on 3 March 2012). 
The Hu leadership has in particular taken inspiration from the Maoist tradition of wufa wutian ("no law, no heavenly justice") in hitting out at real and potential enemies of the regime. The years 2007 and 2008 marked a pronounced deterioration of the legal system as the Party's zhengfa wei, or Central Commission on Legal and Political Affairs (CCPLA), was given more authority than ever to closely supervise the operations of judges and lawyers. Hu pointed out at a national conference on legal and judicial matters in late 2007 that the foremost task of judges and law-enforcement cadres was to "uphold party leadership" and to "serve the party's interests." The Party chief also mentioned goals such as "serving the people" and "safeguarding the sanctity of the Constitution and the law"; but these two objectives paled beside that of sub-serving the CCP. (66)

In March 2008, Wang Shengjun, a former police officer and CCPLA bureaucrat who does not have a law degree, was appointed President of the Supreme People's Court, China's equivalent of Chief Justice. Ridiculed as a famang (legal ignoramus) by liberal legal scholars, Wang has since urged the nation's judges to fulfil political missions such as "promoting stability" and "ensuring social harmony." Wang also called upon judges to "ensure the correct political direction of the people's courts" and to rally behind the leadership of the "Party central authorities with comrade Hu Jintao as general secretary." (67) It is interesting that in his talks to judges, Wang has often admonished them to "deeply study the 'two major theoretical systems' of Mao Zedong Thought and socialism with Chinese characteristics." Like other senior cadres, the chief justice likes to engage in "red tourism." While visiting the "revolutionary mecca" of Ruijin, Jiangxi Province, in 2010, Wang praised the contributions of the CCP founders such as Mao, Zhu De, and Zhou Enlai: "Ruijin is the cradle of the People's Republic of China," he said. "It is also the wellspring of people's justice, as well as the root of the people's courts." (68)

It is also significant that princeling Bo was subjected to repeated attacks by liberal lawyers and law professors for imposing "rough justice" on Chongqing. In the course of his anti-triad campaign, then-Party secretary Bo was said to have put pressure on local judges to expedite convictions. Renowned defence attorney Li Zhuang, who acted for alleged triad boss Gong Gangmo, was convicted by the Chongqing court of perverting the course of justice. This caused such a big uproar in the Chinese legal community that Li was released unconditionally in 2011. The former Chongqing party boss was also accused of harassing residents who did not agree with his crypto-Maoist campaigns. For example, blogger Fang Hong, a 45-yearold retired forestry bureau official, was in early 2011 sent to reformthrough-labour for daring to point out in his microblog that Bo had been manipulating the legal system for political ends. ${ }^{(69)}$

\section{How the Maoist revival helps strengthen the Gang of Princelings and the legitimacy of the "red aristocrats"}

As with most political trends in China, the resuscitation of Maoist norms is intricately related to factional intrigue. Jockeying for position between the two major CCP cliques - the Gang of Princelings and the CYL Faction has intensified in the run-up to the 18th CCP Congress. At this critical conclave slated for 2012, the Fourth-Generation leadership under President $\mathrm{Hu}$ and Premier Wen is due to yield power to the Fifth-Generation leadership, or cadres born in the late 1940s to mid-1950s. As we saw in earlier sections, Bo Xilai and Vice-President Xi Jinping, two prominent princelings, are among the most ardent architects of the quasi-Maoist renaissance. Implicit in the princelings' re-hoisting of the Maoist flag is a veiled critique of the policies undertaken by $\mathrm{Hu}$ and his CYL Faction, which seem to have exacerbated the polarisation of rich and poor and spawned a kind of crass commercialism that runs counter to Maoist spiritual values. ${ }^{(70)}$

Much more significantly, the princelings are using the Maoist crusade to lobby for more clout and authority in the polity. The political fortune of the Gang of Princelings suffered quite a blow during the first decade of the Era of Reform. Deng Xiaoping was against allowing too many princelings to monopolise Party and government posts. In the early 1980s, Deng reportedly indicated in an internal Party meeting that the proportion of taizidang Central Committee members should be limited. Instead of seeking a political career, princelings were encouraged to go into business. ${ }^{(71)}$ It was no accident that both of the patriarch's sons, Deng Pufang and Deng Zhifeng, were successful if also controversial businessmen. The same goes for the children of Third- and Fourth-Generation leaders including Jiang Zemin, Zhu Rongji, $\mathrm{Hu}$ Jintao, and Wen Jiabao. ${ }^{(72)}$

The political careers of many princelings were affected by Deng's stricture. Bo, for example, did not get into the Central Committee until 2002, even though he had years earlier established himself as a formidable "warlord" in industrialised Liaoning Province. A number of high-profile princelings, including Xi Jinping, Wang Qishan (son-in-law of the late Vice-Premier Yao Yilin), and Deng Pufang made it into the Central Committee also at a relatively late stage of their careers. The trio were first elected into the Central Committee in 1997 as alternate, or second-tier and non-voting, members. Moreover, Xi got the least - and Deng and Wang respectively the second and seventh lowest - number of votes among the 151 alternate members. ${ }^{(73)}$ By the 2000s, however, the princelings had made a strong comeback. Bo's fairly successful Maoist campaign was widely seen as a Machiavellian manoeuvre to enable him to secure a slot on the new PBSC that will be established at the $18^{\text {th }}$ Party Congress. Wang, who became Vice-

66. Cited in Willy Lam, "The politicization of China's law-enforcement and judicial apparatus," in JeanPhilippe Béja, The Impact of China's 1989 Tiananmen Massacre, London, Routledge 2011, pp. 125141.

67. Cited in "Wang Shengjun urges the strong development of superior tradition and the assiduous implementation of scientific development," Legal Daily, 1 July 2011, http://news.163.com/ 11/0701/20/77TGR5VK00014AEE.html (consulted on 3 March 2012).

68. Cited in "President of the Supreme People's Court Wang Shengjun inspects Ruijin, Jiangxi Province," www.sach.gov.cn, 8 August 2010, www.sach.gov.cn/tabid/297/InfolD/25798/Default.aspx (consulted on 3 March 2012).

69. For a discussion of Bo's lack of respect for rule of law, see, for example, Kathrin Hille, "Dissent lands Chinese blogger in labour camp," Financial Times, 7 June 2011, www.ft.com/intl/cms/s/0/01ffgfa0-9114-11e0-acfd-00144feab49a.html\#axzz1XAHnV07W (consulted on 3 March 2012). Also see Willy Lam, "Chongaing's mafias expose grave woes in China's legal apparatus," China Brief, 4 November 2009, www.jamestown.org/single/?no_ cache $=1 \&$ tx_ttnews\%5Btt_news\%5D=35689 (consulted on 3 March 2012); lan Johnson, "Trial in China tests limits of legal system reform," The New York Times, 20 April 2011, www.nytimes.com/2011/04/20/world/asia/20china.html?src=me (consulted on 3 March 2012).

70. For a discussion of the internecine bickering between the Gang of Princelings and Hu Jintao's Communist Youth League Faction, see, for example, Qiu Xiaotong, "Bo Xilai's campaign of hitting the triads and singing red songs has led to a schism within the CCP leadership," Frontline monthly (Hong Kong), September 2011

71. For a discussion of Deng Xiaoping's views toward the princelings, see, for example, Qin Hui, "On certain questions about the Cultural Revolution," China-Review.com, 19 January 2011 (accessible on 3 March 2012 at http://blog.renren.com/share/237211801/6943594490).

72. For a discussion of the business activities of the taizidang, see, for example, Catherine Tai, "The 'Princelings' and China's Corruption Woes," Center for International Private Enterprise, 5 August 2009, www.cipe.org/blog/?p=2844 (consulted on 3 March 2012); see also Michael Sheridan, "China snaps at its junior princelings," The Times of London, 6 June 2010, www.timesonline.co.uk (accessible on 3 March 2012 at www.freerepublic.com/focus/f-news/2528715/posts).

73. See "List of members and alternate members of the 15th CCP Central Committee," Xinhua News Agency, 11 July 2008, www.gov.cn/test/2008-07/11/content_1042275.htm (consulted on 3 March 2012). 
Premier in March 2008, is heavily tipped to get into the PBSC at this crucial congress. ${ }^{74)}$

Moreover, the princelings' clout is particularly pronounced within the People's Liberation Army. Several dozen major-generals, lieutenant-generals, and full generals boast distinguished pedigrees. The following princeling generals are considered to have a high chance of making the policy-setting Central Military Commission that will be formed at the $18^{\text {th }}$ Party Congress: Air Force Commander Xu Qiliang, Deputy Chief of General Staff Ma Xiaotian, General Logistics Department Political Commissar Liu Yuan, Political Commissar of the Second Artillery Corps Zhang Haiyang, and Shenyang Military Region Commander Zhang Youxia. (75)

The princelings are cunningly using the Maoist-restitution drive to further exploit their advantage of illustrious lineage. After all, as the famous Chinese proverb goes: "He who has won heaven and earth has the right to be their rulers." This was the basis of the "revolutionary legitimacy" of the First- and Second-Generation leadership under Mao and Deng respectively. As the sons and daughters of Long March veterans, princelings regard their "revolutionary bloodline" as a prime political resource. ${ }^{(76)}$ Thus, while visiting the "revolutionary mecca" of Jinggangshan in Jiangxi Province in 2008, Xi paid homage to the "countless martyrs of the revolution who used their blood and lives to win over this country." "They laid a strong foundation for the good livelihood [we are enjoying]," he said. "Under no circumstances can we forsake this tradition." (77) Similarly, while marking National Day on 1 October 2008, Bo urged Chongqing's cadres "to forever bear in mind the ideals and hot-blooded [devotion] of our elders." "Forsaking [their revolutionary tradition] is tantamount to betrayal," Bo instructed. (78)

It is also not surprising that the military offspring of Party elders and Long March-generation generals have since 2010 been a strong force behind the changhong movement. Take, for instance, the high-powered group called "Singing Troupe of 100 Offspring of Generals." Senior members of the troupe include the sons and daughters of Marshals Chen Ye, Nie Rongjun, Luo Rongheng and He Long, respectively Chen Haosu, Nie Li, Luo Dongjin, and He Xiaoming. ${ }^{(79)}$ Owing to the aura of respectability attached to their fathers, these military taizidang felt a sense of pride in singing "revolutionary songs," many of which were associated with the Great Helmsman. Like their civilian counterparts such as Xi Jinping, military princelings want to play up the symbolic value of their pedigree - and their fitness to play a major role in Chinese military and political affairs. ${ }^{(80)}$

\section{Is the ouster of Bo an indication of the end of the Maoist campaign?}

Things began to fall apart for Bo Xilai before Chinese New Year in January 2012, an intriguing course of events that led to the "suspension" of his Politburo membership in April. Given that Beijing has been reluctant to release critical evidence regarding this mammoth case, the following account has been pieced together from reports from the foreign and Hong Kong press - as well as other credible sources in Beijing. Bo the regional "warlord" began to fall out with one of his closest aides, then-Chongqing vice-mayor and head of public security Wang Lijun. Wang, known as a "national anti-triad hero" for his role in smashing triad gangs, told his boss he was investigating Bo's wife, the power lawyer Gu Kailai, for possible involvement in the death of British businessman Neil Heywood. Bo was so mad that he relieved Wang of his police duties and instead put the vicemayor in charge of higher education and the environment. ${ }^{(81)}$ Seeing the writing on the wall, Wang, who is believed to also have been under investigation for corruption offences during the long years that he served in Liaoning Province, tried to seek political asylum at the Chengdu US Consulate General on 6 February. One day later, Wang emerged from the consulate and was taken to Beijing by senior officials from the Ministry of State Security.

At least publicly, Bo seemed unfazed. He attended the annual National People's Congress that opened on 5 March. At an NPC press conference, the princeling admitted that he had made the mistake of yongren bucha, or "hiring officials without careful consideration." But he defended himself against innuendo that his wife and kin were involved in improper economic dealings. On 15 March, however, Xinhua announced in a terse statement that Bo had been relieved of his duties as Chongqing Party secretary. And on 10 April, the Party leadership suspended Bo of his Politburo and Central Committee membership on account of "serious discipline violations." Xinhua reported that Gu was complicit in Heywood's death. Beijing was awash with rumours that Bo was hatching a plot against $\mathrm{Hu}$ and $\mathrm{Xi}$ Jinping, who is due to take over the post of Party General Secretary at the $18^{\text {th }}$ CCP Congress. ${ }^{(82)}$ The main factor behind Bo's ouster seemed to be the animosity between the ultra-ambitious princeling on the one hand, and $\mathrm{Hu}$ Jintao and Wen Jiabao on the other. There was also a bitter power struggle between the Gang of Princelings and the CYL Faction. Of the nine PBSC members, only Hu has not visited Chongqing since Bo was transferred there in late 2007. Premier Wen was briefly in the metropolis in December 2008 - mainly to assess the impact of the global financial crisis on western China. But he said nothing about the anti-triad or the changhong movements that Bo had just

74. For a discussion of the prospects of Bo and the princelings at the 18th CCP Congress, see, for example, Lin Heli, "The political conspiracy behind the changhong campaign," Apple Daily (Hong Kong), 23 June 2011; Willy Lam, "Heir apparent showing his stripes," Asia Times, 22 December 2010, www.atimes.com/atimes/china/ll22ad01.html (consulted on 3 March 2012); and Kathrin Hille and Jamil Anderlini, "China: Mao and the next generation," Financial Times, 2 June 2011, www.ft.com/intl/cms/s/0/eb239472-8d48-11e0-bf23-00144feab49a.html\#axzz1XAHnV07W (consulted on 3 March 2012).

75. For a discussion of the princelings in the PLA, see, for example, Willy Lam, "The power of Xi Jinping has become consolidated," Apple Daily, Hong Kong, 24 August 2011.

76. For a discussion of the rise of cadres with "revolutionary bloodlines," see, for example, Chen Pokong, "The CCP has elevated a large number of princelings," www. Chinesepen.org, 9 December 2007, www.chinesepen.org/Article/hyxz/200712/Article_20071209210450.shtml (consulted on 3 March 2012)

77. Cited in "Xi Jinping emphasises the need to develop the villages through reform and innovation, and to strengthen party construction by developing our superior tradition," CCTV, 15 October 2008, http://tv.people.com.cn/GB/61600/8179126.html (consulted on 3 March 2012).

78. "Bo Xilai: We must remember forever the ideals and hot-bloodedness of our elders," Chongqing Daily, 2 October 2008, http://club.china.com/data/thread/1011/2344/86/22/3_1.html (consulted on 3 March 2012).

79. For a discussion of the activities of the Singing Troupe of 100 Offspring of Generals, see for example, "Offspring of the generals sing red songs; their enthusiasm spreads throughout the land," Dazhong Daily (Shandong), 26 June 2010, www.dzwww.com/shandong/sdnews/201006/ t20100627_5679023.htm (consulted on 3 March 2012).

80. For a discussion of the "military princelings," see, for example, Lin Heli, "Factors behind Xi Jinping's consolidation of power," Apple Daily, 24 August 2011.

81. For an account of the Wang Lijun case, see, for example, Chris Buckley and Sui-Lee Wee, "Chinese official takes 'leave' in blow to ambitious Bo Xilai," Reuters, 8 February 2012, www.reuters.com/article/2012/02/08/us-china-official-idUSTRE8170B920120208 (consulted on 3 March 2012); Michael Bristow, "Chongqing policeman Wang Lijun mystery deepens," BBC news, 9 February 2012, www.bbc.co.uk/news/world-asia-china-16958981 (consulted on 3 March 2012).

82. For an account of the myriad charges levied against the Bos, see, for example, Sharon LaFraniere and John F. Burns, "Briton's wanderings led him to heart of a Chinese scandal," The New York Times, 11 April 2012, www.nytimes.com/2012/04/12/world/asia/bo-xilai-scandal-and-the-mysteriousneil-heywood.html? pagewanted=all (consulted on 3 March 2012); for a description of the business operations of the Bos, see, for example, Jeremy Page, Brian Spegele, and Steve Eder, "'Jackie Kennedy of China' at Center of political drama," The Wall Street Journal, 8 April 2012, http://online.wsj.com/article/SB10001424052702303299604577327472813686432.html?mod=WSJ_hp _us_mostpop_read (consulted on 3 March 2012). 
launched. ${ }^{(83)}$ As we saw in the above sections, while there were major differences between the philosophies and ideology of Bo and Wen, Bo's cryptoMaoist ideals and statecraft were not significantly different from those of either Hu or other BPSC members such as Xi Jinping, Li Changchun, or Zhou Yongkang. It thus seems evident that Bo's disgrace will not necessarily mean the end of either the "Chongqing model" or the Maoism movement.

It is true that at Wen's penultimate NPC international press conference just one day before Bo's dismissal as Chongqing chief, the liberal premier indirectly criticised Bo by warning against "a return of the Cultural Revolution." In his meeting with veteran Hong Kong-based NPC member Wu Kangmin in 2011, Wen also decried the possible resuscitation of "the remnant poison" of the Cultural Revolution. ${ }^{\left({ }^{84}\right)}$ Immediately after Bo's downfall, there were signs that the Party leadership was reining in the crypto-Maoist excesses associated with Bo and the Chongqing model. For example, several websites that used to sing the praises of Bo's ideas - wyzxzx.com and Redflag.net - were closed down for "maintenance." Yang Fan, an economics and politics professor at the China University of Politics and Law who had eulogised the Chongqing model, said he would have to take a second look at the track record of Bo and his associates. There was also speculation that Wen had taken advantage of Bo's political demise to push for his long-time goal of changing the official verdict of the 1989 pro-democracy student movement. $\left.{ }^{85}\right)$

However, it was evident that the bulk of the political manoeuvres and ideological campaigns undertaken by the Hu leadership in the wake of the Wang Lijun and Bo Xilai incidents were geared toward upholding stability and political conformism among civilian and military officials. Apart from the Mao-oriented websites, a large number of liberal blogs and websites were put out of action. Several Netizens were arrested for "spreading rumours" on the information superhighways. Cyberpolice departments also launched a nationwide campaign to clear the Net of criminal and politically incorrect elements. The treatment of dissidents and human rights activists including Ai Weiwei, Gao Zhisheng, and Chen Guangcheng remained extremely harsh. Chen was forced to seek refuge in the American Embassy in Beijing in late April. ${ }^{(86)}$ A number of Chinese intellectuals saw Bo's political demise as a vindication of Premier Wen's advocacy of reform - and a possible harbinger of some form of political loosening up to come in 2013. For example, Wang Kang, a Chongqing-based scholar and documentary filmmaker, said that "Bo's ouster marks a turning point in China's history and gives China an opportunity." Yet Wang was clear-headed enough to note that the victory scored by the likes of Wen was "still very fragile." Other intellectuals are less sanguine about what Bo's fall may portend. For example, Wu Si, a famous public intellectual associated with the liberal journal Yanhuang Chunqiu, told the foreign media he was disappointed that the Bo incident had not resulted in any policy liberalisation. "On first look, I think it's a good thing," Wu said with reference to the impact of Bo's downfall on political developments. "But on second look, I think, not necessarily." (87)

Actually, the loyalty drives implemented after Bo's ouster seemed to tally more with the Maoist ideal of the yiyantang or "one voice chamber" rather than political reforms advocated by the likes of Premier Wen. Emblematic of these calls for uniformity of thinking and unquestioned loyalty to the Party leadership was the Campaign to Learn from Lei Feng that was organised in different provinces and PLA units. (88) "Proletariat paragon" Lei Feng was lionised by Mao Zedong in the 1950s for his unreserved fealty to the Party central authorities. For example, in a speech marking the Learn From Lei Feng Campaign in Hunan Province, Party Secretary Zhou Qiang pointed out that "the Lei Feng spirit has clear-cut contemporary traits." "The Lei Feng spirit will never become obsolete; it is eternal in nature," said Zhou, a notable Sixth-Generation tuanpai politician who is rumoured to be a post$18^{\text {th }}$ Congress candidate for the post of Chongqing party boss. ${ }^{(89)}$

PLA units at headquarters and regional levels underwent a propaganda exercise entitled "We must inherit Lei Feng's gun." According to CMC ViceChairman General Xu Caihou, CMC Chairman Hu instructed officers "to push forward the Lei Feng spirit with a strong sense of political responsibility and a high degree of self-consciousness." (90) One week after Bo's disgrace, the Liberation Army Daily ran a commentary entitled "Opposing and Getting Rid of Liberalism." It cited Mao Zedong's article "In Opposition to Liberalism," which was written 75 years ago. The Great Helmsman pointed out at the time that "liberalism within the collective organs of the revolution is very detrimental" because this would foster problems such as "weak organisation" and "divergence of views." (91)

The new line on political rectitude and conformism was laid down by Politburo member and CCP Organisation Chief Li Yuanchao. In the wake of the Bo scandal, Li asked officials to "seriously implement all regulations regarding clean government and discipline." "Cadres must under all circumstances be able to uphold their sense of morality, maintain good behaviour, and not succumb to corruption," Li warned. Li added on another occasion that in picking cadres for senior positions, the Organisation Department "must first scrutinise their political standpoint... and political morality." (92) In other words, what matters most is a cadre's total obeisance to instructions from on high. A similar note was struck by Xi Jinping in a long article

83. For a discussion of Hu Jintao and Wen Jiabao's views on Bo and his Chongqing experiments, see, for example, Willy Lam, "Hu Jintao draws blood with the Wang Lijun scandal," China Brief, 2 March 2012, www.jamestown.org/programs/chinabrief/single/?tx_ttnews\%5Btt_news\%5D=39092\&tx_ ttnews\%5BbackPid\%5D=25\&cHash=4c9b60e4f8bf8dd6bc9f171a1e2a5e8c (consulted on 3 March 2012); see also "Premier Wen Jiabao inspects Chongqing," People's Daily, 23 November 2008, http://paper.people.com.cn/rmrb/html/2008-12/23/nw.D110000renmrb_20081223_902.htm (consulted on 3 March 2012).

84. For a description of Wen's attitude toward the Chongqing affair and the Cultural Revolution, see, for example, Jamil Anderlini, "Wen lays ground for Tiananmen healing," Financial Times, 20 March 2011, www.ft.com/intl/cms/s/0/13c6fcb2-7285-11e1-9be9-00144feab49a.html?ftcamp=published_links/rss/home_uk/feed//product\#axzz1prU05XIv (consulted on 3 March 2012).

85. See Shi Jiangtao, "Maoist sites closed over Bo support," South China Morning Post, 7 April 2012; Author's telephone interview with Yang Fan, 8 April 2012.

86. For a discussion of new constraints put on the Internet, see, for example, Josh Chin and Brian Spegele, "China reins in Bo Xilai chatter online," The Wall Street Journal, http://online.wsj.com/article/SB10001424052702303812904577295462500007558.html (consulted on 3 March 2012). For a discussion of China's treatment of dissidents in recent months, see, for example, Chris Buckley, "China parliament unveils dissident detention powers," Reuters, 8 March 2012, www.reuters.com/article/2012/03/08/us-china-npc-law-idUSBRE8270BP20120308 (consulted on 3 March 2012).

87. Cited in Michael Wines, "A populist's downfall exposes ideological divisions in China's ruling party," The New York Times, 4 April 2012, www.nytimes.com/2012/04/07/world/asia/bo-xilais-ousterexposes-chinese-fault-lines.html (consulted on 3 March 2012); Keith Richburg, "With Bo Xilai's ouster, China's premier pushes more reform," The Washington Post, 27 April 2012, www.washingtonpost.com/world/with-bo-xilais-ouster-chinas-premier-pushes-reform/2012/04/ 26/glQAvhoCkT_story.html (consulted on 3 March 2012).

88. For a description of a typical Lei Feng spiritual campaign, see, for example, Feng Chunmei, "Going along with the spirit of Lei Feng," People's Daily, 22 March 2012, http://military.people.com.cn/ GB/17453870.html (consulted on 3 March 2012).

89. Cited in "Zhou Qiang: The core of the Lei Feng spirit will never be obsolete," Hunan Daily, 15 February 2012, http://news.xinhuanet.com/politics/2012-02/17/c_122718804.htm?prolongation=1 (consulted on 3 March 2012).

90. Cited in "Senior PLA officers issue the demand of 'taking over the gun of Lei Feng'," Wen Wei Po (Hong Kong), 18 March 2012, http://news.wenweipo.com/2012/03/18/IN1203180002.htm (consulted on 3 March 2012).

91. Cited in "Countering and abolishing liberalism," Liberation Army Daily, 21 March 2012.

92. Cited in "Li Yuanchao: Selecting virtuous cadres should first examine their political standpoint," Wen Wei Po, 6 April 2012, http://news.wenweipo.com/2012/04/06/IN1204060006.htm (consulted on 3 March 2012). 
in the Party's theoretical journal Seeking Truth. The "crown prince" called upon officials to "safeguard the purity of the party." "We must resolutely stop and combat any wrong political tendencies that veer from the party's basic lines," he indicated. "Leading cadres must resolutely uphold the Party's principles, charter, goals, and policies." "(93) There seems little doubt that these homilies were issued to rein in centrifugal tendencies exposed by the Bo Xilai affair.

The powers-that-be, then, did not seem to realise that the Bo affair - including rumours that he was contemplating the moral equivalent of a coup d'état against the Hu-Wen leadership - was a testimony of the Maoist elements in CCP politics, particularly the rule of personality. It seems clear that the only way to prevent a recurrence of the Bo disaster - as well as the Cultural Revolution - was to press ahead boldly with real political reform. It is therefore unfortunate that the reaction of the Hu leadership was to put an even tighter squeeze on liberalisation, including the possibility of a higher degree of free thinking among cadres and intellectuals.

\section{Conclusion: Preserving the status quo at all cost}

For many intellectuals, changhong and other manifestations of the Maoist resurgence are a contradiction in terms. As He Bing, a top law professor at the China University of Political Science and Law put it: "In this absurd time, they encourage you to sing revolutionary songs, but they do not encourage you to wage a revolution." For Renmin University political scientist Zhang Ming, the ditties featured in changhong performances could at most be called "pink songs." "Red songs are mostly about revolution and violence," he said. "Now they only use red songs to praise the Party and Party members; so it's pointless." (94)

Indeed, the Maoist revival says much about the CCP's top priority of preserving the status quo, especially its status as "perennial ruling party." Beijing's nervousness about the loss of yiyuanhua - or "monolithic" - control over ideology and politics is fully reflected by the authorities' elaborate studies of the reasons behind the fall of the USSR and the Communist Party of the Soviet Union (CPSU). Most mainstream theorists attribute the CPSU's demise to Soviet leaders' failure to preserve "purity of thought" by sticking to Marxism and Stalinism. Senior ideologue Zhang Quanjing said it well when he put the blame of the CPSU's collapse on de-Stalinisation. "The first major reason behind the death of the CPSU is the negation of its leadership and negation of party history," he said. Turning to China, Zhang indicated: "Since the era of reform, the West has sped up the pace of Westernising and dividing up China. One of their main methods is to besmirch and vilify Mao Zedong." "(95) In the same vein, CASS Vice-President Li Shenming pointed out that the dissolution of the USSR stemmed from Soviet leaders' "getting away from and eventual betrayal of Marxism and socialism." (96) Moreover, Li asserted, the Soviet state-security apparatus failed to put the lid on dissent. The ideologue fingered three forces as playing a pivotal role in chipping away at the CPSU's authority: underground publications, dissidents, and NGOs. ${ }^{(97)}$ As discussed above, the resuscitation of Maoist practices has served the purpose of promoting the uniformity of thought - and weeding out dissidents as well as bourgeois-liberal intellectuals and organisations.

While it is not the purpose of this paper to discuss China's future policies, it is probable that the Hu Jintao - and Xi Jinping - leadership's obsession with preserving the CCP's monopoly on power could leave them ill-disposed and ill-equipped to rekindle those economic, administrative, and political reforms that have been put on the back burner for the past couple of decades. As pointed out in an earlier section, $\mathrm{Xi}$, who will be the PBSC member in charge of the CCP's overall ideological orientation, is a firm believer in the relevance and viability of Maoist thinking. Internationally, the financial and debt problems encountered by the US and the EU - and China's "white knight" role in purchasing American and European bonds - will render the CCP even more confident of its long-standing policy of upholding one-party authoritarian rule. Pressure from abroad regarding the CCP's human rights and related abuses is also set to decrease. The possibilities are reasonably high that Bo Xilai's downfall notwithstanding, much of the restitution of Maoist norms will continue into the Xi Jinping era. While a kind of spring of democracy has swept through large swathes of the Middle East and North Africa since early 2011, the Middle Kingdom seems destined to be shrouded in deep winter for the foreseeable future.

I Willy Lam is an Adjunct Professor in the History Department as well as in the Master's Program in Global Political Economy of the Chinese University of Hong Kong. He is also an Adjunct Professor of China Studies at Akita International University, Japan.

93. Cited in "Xi Jinping talks about upholding the party's purity," Seeking Truth (Beijing journal), 16 March 2012, http://china.huanqiu.com/roll/2012-03/2528962.html (consulted on 3 March 2012).

94. Cited in Edward Wong, "Repackaging the revolutionary classics of China," The New York Times, 29 June 2011, www.nytimes.com/2011/06/30/world/asia/30redsong.html?pagewanted=all (consulted on 3 March 2012).

95. Zhang Quanjing, art. cit.

96. Cited in Li Shenming, "The fundamental reason of the break-up of the Soviet Union is the degeneration of the Communist Party of the Soviet Union," People's Daily, 25 March 2011, http://theory.people.com.cn/GB/14239005.html (consulted on 3 March 2012).

97. Cited in Li Shenming, "Lessons from ideological work in the Soviet Union," Global Times, 29 August 2011, http://opinion.huanqiu.com/roll/2011-08/1954412.html (consulted on 3 March 2012). 